\title{
クッキーのショートネス発現におけるデンプンの寄与
}

\author{
和 田 淑 子*, 橋 本 慶 子** \\ * 関東学院女子短期大学家政科 \\ ** 青山学院女子短期大学家政学科
}

\section{Contribution of Starch to the Development of Shortness in Cookies}

\author{
Yoshiko WADA* and Keiko HASHIMOTO** \\ * Department of Home Economics, Kanto Gakuin Women's Junior \\ College, Kanazawa-ku, Yokohama 236 \\ ** Department of Home Economics, Aoyama Gakuin Women's \\ Junior College, Shibuya-ku, Tokyo 150
}

Nippon Eiyō Shokuryō Gakkaishi (J. Jpn. Soc. Nutr. Food Sci.) 40, 227 232 (1987)

Four types of cookies (A, B, C, and D) were made by using each of the four kinds of wheat flour: A, unmodified flour; B, flour with modified starch; C, flour with modified gluten; and D, flour with modified starch and modified gluten. These cookies were made without the addition of fat and their shortness scores were evaluated by sensory tests. High scores were obtained from cookie B and cookie D. Their microstructures were similar to that of a highly shortened cookie made with a sufficient amount of fat. The dough from flour $B$ was harder and that from flour $C$ was softer than that from flour A. The gelatinization of wheat starch delayed as the amount of the added fat increased. The mobility of an oil-soluble free radical used as a spin probe was depressed when wheat starch was gelatinized. From these results it was proposed that the development of shortness in cookie was due to entrapment of alkyl moieties of the fat into the hydrophobic helical coils of starch molecules.

(Received November 20, 1986)

クッキーは広い年龄層の人々に好まれ，低水分のため 比端的長期保存ができる日常性の高い食品である。製法 や材料配合のちがい水よりハード、ソフトおよびフォン シーなどの種類に分けられるが，いずれる小麦粉生地に 練りこまれた油脂の効果で，油脂の配合割合が多くなる 汪どるろくてさくさくした特有の食感をもつ。この食感 をショートネスという。クッキーの食味を構成する要因 には外钼, 風味, 甘味, 硬さ、食感があげられるが, こ れらの要因のらち食味に最も寄与するのはショートネス で代表される食感である。

クッキーの基本材料は小麦粉, 油脂および水で, 補助 材料は砂糖, 卵およびベーキングパウダーである。シ ョートネスはこれらの材料の配合割合によって影離を受 ける1。上述の材料のらちショートネス発現に最も寄与 するのは油脂である(1) 。補助材料である砂糖は油脂の 目合割合との兼ねあいによってショートネスに奇与する といわれているら。著者らははクッキーの基本材料およ

* 于236 横浜市金沢区六浦町 4834

** T150 東京都沾谷区渋谷 4-4-25
び補助材料の配合比を変化させて, ショートネス発現に 関与する要因を検討し, 油脂量が多いと良好なショート ネスをむつクッキーが得られ，破楉と卵が多いとショー トネスの低いクッキーが得られるといら結論を得だ。

本研究は小表粉と水だけを材料としたモデル系で，デ ンプンおよびグルテン修飾試薬がクッキーの物性に与え る影響をしらへ，ショートネス発現の機構を解明するこ とを目的とした。デンブンは糊化過程で, クルテンは生 地調製時の擋拌過程で会合し，碎けにくい物性を発現す ると考えられ，碎けやすい物性を発現させるためには， デンプンおよびクルテンの会合を阻止しなければならな いはずである。したがって，本研究ではデンブンおよび グルテンの会合を阻止するための攸飾㨈として，それぞ れヨウ素およびシステインを用いこれらを混合するこ とによってデンプンおよびクルテンを修飾した小麦粉を 用いて調製したクッキーの性状をしらべショートネス 発現機構の推定を試みた。 


\section{実 験 方 法}

\section{1. 材 料}

クッキー主原料として小麦粉（月桂冠印，昭和産業） および水素添加ヤシ油（日本油脂）を用いた。この水素 添加ヤシ油の酸価は 0.09 であった。デンプン修飾剂お゙ よびグルテン修飾剤として用いたヨウ素および Lーシス テイン, ヨウ素溶解剤として用いたヨウ化カリウムは試 薬級の市肘品である。小麦デンプンは Anderson ら6)の 方法で上述の小麦粉から調製した。

\section{2. クッキーの調製}

クッキーの材料配合を Table 1 に示した。小麦粉に水 を加え, $25^{\circ} \mathrm{C}$ の佰温室でミキサー（松下電器, ケーキ マスター MK-710) を用いて $420 \mathrm{rpm}$ で 8 分間撹捧し て得た生地を $3 \mathrm{~mm}$ の厚さに延ばしてポリプロピレン 膜で包み, $-20^{\circ} \mathrm{C}$ で 10 分間放置後, 直径 $3.5 \mathrm{~cm}$ の円 形に型抜きした。システイン、ヨウ素およびョウ化カリ ウムは使用する水にあらかじめ溶かしておいた。油脂を 用いる標準クッキーの場合には，薄切にした水素添加ヤ シ油と小麦粉を上述のミキサーで $420 \mathrm{rpm}, 2$ 分間擋䢁 し，水を加えてさらに 8 分間擋拌した。成形操作は上述 の方法と同様である。成形した生地をガスオーブン（リ ンナイ，RO-450 型）を用いて $195 \pm 3^{\circ} \mathrm{C} て ゙$ 焼成した。 焼成時間は Table 1 のとおりである。オーブンから出し たクッキーは 1 時間室温で冷却してからシリカゲル上で $20^{\circ} \mathrm{C}$ で保存した。

\section{3. 官 能評価}

12 名からなる専門ハネル（日本油脂株式会社パネル） により, Stone ら》の定量的記述解析法を使って連続数 として各クッキーのショートネスを評価した。試料クッ キーを䊀み砕いたときの食感と，指で割ったときの感覚 の両者からショートネスを評価した。尺度の基準とし
て，対照クッキー（Table 1 の control) のショートネ スを 1, 標準クッキー (Table 1 の reference) のショ ートネスを 10 とするよらに指示した。尺度の基洒とし たクッキーがどのようなものかについてはバネルに知ら せなかった。ショートネススコアは評価値の平均値に標 準誤差をつけて表わした。

\section{4. 赫胡解析}

独立変数としてデンプン隹飾剤の添加, 無添加お゙び グルテン修飾剤の添加，無添加の 2 アイテム，4 カテコ リーを用いて，上述の方法で調製したクッキーのショー トネススコアを数量化理論 I 類 ${ }^{8}$ によって分析し，偏相 関俰数を求めた。

\section{5. 走查型電子顥微鏡籍㖨}

各クッキーをかみそりで切断し，金蒸着したものを試 料とした。試料は走査型電子顕微鏡（日立， S-510 型) で 40 倍および 1,000 倍の倍率で観察した。

\section{6. 生地の物性}

AACC 法 54-219) に準じて, ファリノグラフ (Brabender 社）の試料室に小麦粉 $300 \mathrm{~g}$ と水 $150 \mathrm{ml}$ を入 れ, $30^{\circ} \mathrm{C}$ で 20 分間擋拌しながら生地の物性特性値の変 化を記録した。ヨウ素, ヨウ化カリウムおよびシステイ ン（配合比は Table 1 と同じ）は使用する水にあらかじ め溶かしておいた。

\section{7. デンプンの物性}

小麦デンプン, 水および水素添加ヤシ油の配合を重量 比で $12: 90: 0,12: 90: 6,12: 90: 12$ とした各試料 $(500 \mathrm{~g})$ を AACC 法 22-109) に準じて測定に供した。小麦 デンプンと水素添加ヤシ油をフミログラフ (Brabender 社）の試料容器に入れ， $30^{\circ} \mathrm{C} に$ 保温した水を加えて 75 $\mathrm{rpm}$ で 5 分間擋汼した後, $1.5^{\circ} \mathrm{C} /$ 分の速度で $97^{\circ} \mathrm{C}$ まで 昇温し，その間の物性特性値の変化を記録した。

Table 1. Material compositions and baking periods for cookie making.

\begin{tabular}{lrrrrr}
\hline & \multicolumn{5}{c}{ Type of cookie } \\
\cline { 2 - 5 } & Control & $\begin{array}{c}\text { Modified } \\
\text { starch }\end{array}$ & $\begin{array}{c}\text { Modified } \\
\text { gluten }\end{array}$ & $\begin{array}{c}\text { Modified } \\
\text { starch- } \\
\text { modified } \\
\text { gluten }\end{array}$ & Reference \\
\hline Material composition (g) & 100 & 100 & 100 & 100 & 100 \\
Wheat flour & 50 & 50 & 50 & 50 & 23 \\
Water & 0 & 5 & 0 & 5 & 0 \\
Iodine & 0 & 10 & 0 & 10 & 0 \\
Potassium iodide & 0 & 0 & 3 & 3 & 0 \\
L-Cysteine & 0 & 0 & 0 & 0 & 40 \\
Hydrogenated coconut oil & 28 & 28 & 28 & 28 & 16 \\
Baking period (min) & & & & & \\
\hline \hline
\end{tabular}



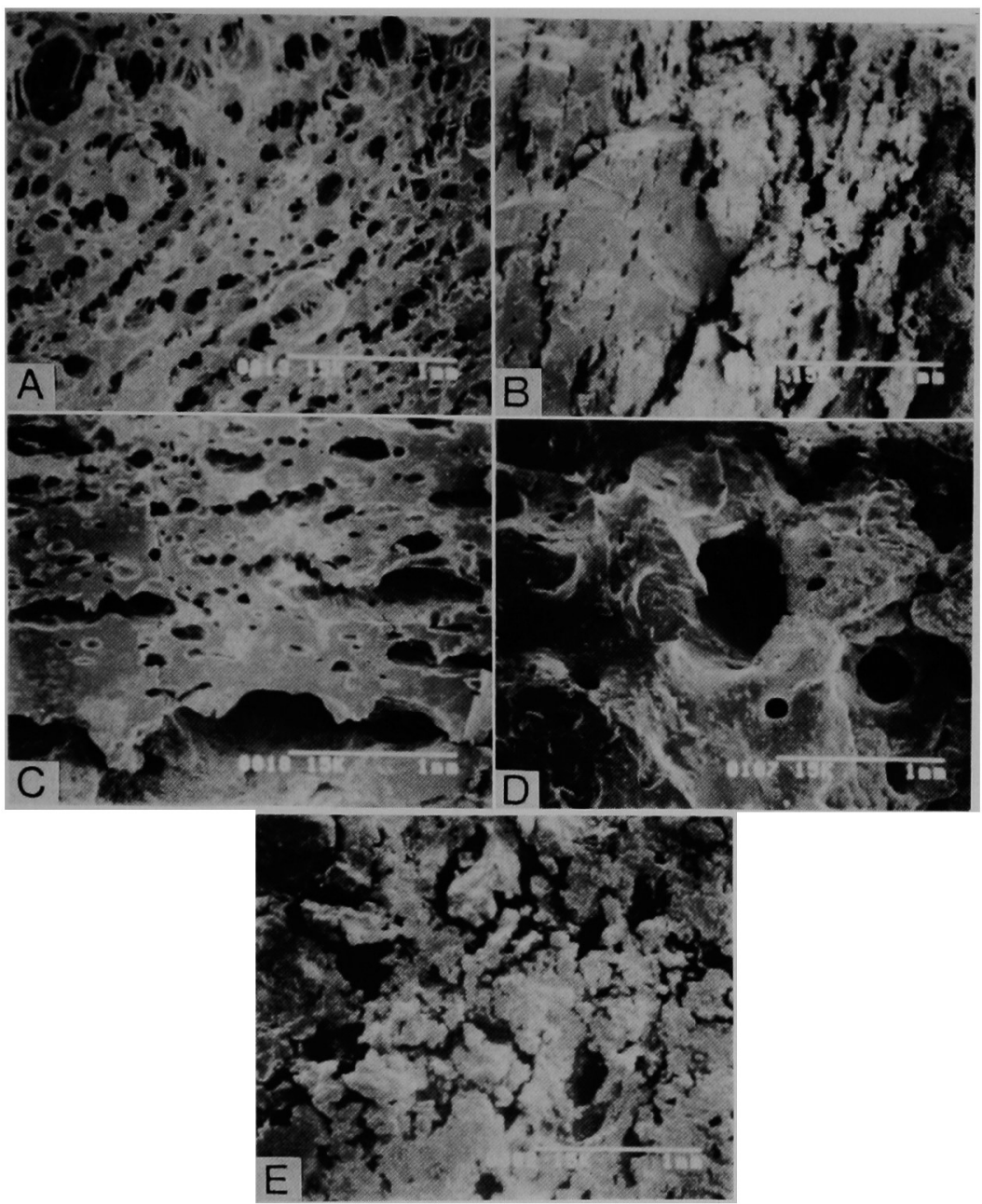

Fig.1. Scanning electron micrographs showing structures of cookies (40 times magnification).

A, control ; B, modified starch; C, modified gluten; D, modified starchmodified gluten; and $\mathrm{E}$, reference.

\section{ESR}

Shenouda および Pigott10) の方法に従った。2-(3carboxypropyl)-4, 4-dimethyl-2-tridecyl-3-oxazolidinyloxyl (Aldrich Chemical Co.) をスピンプロープとして 用いた。スピンプローブを十分量のクロロホルムに溶か し，コーン油（昭和産業）を加えてよく混合した後，減 珐でクロロホルムを溜去した。コーン油中のスピンプロ ーブ濃度は $4 \times 10^{-4} \mathrm{M}$ とした。スピンプロープを溶かし たコーン油（1g）と小麦デンプン（5g）をよく混合し， 水 $(2 \mathrm{ml})$ を加えてさらに混合してから 1 気圧で 10 分 間蒸煮した。蒸煮物を真空乾燥して ESR 測定試料とし た。対照試料にはスピンプローブを溶かしたコーン油を 用いた。スペクトルは電子スピン共鳴装置（日本電子, JES-PE-3X 型）を用いて 9.45 9.55 GHz でスペクト
ルを記録した。振動変調 $100 \mathrm{kHz}, 10 \mathrm{mV}$ のマイクロ波 を入力した。

\section{結果および考察}

対照クッキー, デンプン修飾クッキー，グルテン修飾 クッキーおよびデンプンとグルテンの両者を修飾したク ッキーのショートネスについて官能評価し, ショートネ ス発現に寄与する要因を数量化理論 I 類を用いて解析し た結果，デンプン修飾といらアイテムに対する偏相関係 数は 0.50, グルテン修飾といらアイテムに 対する偏相 関係数は 0.03 であった (Table 2)。この結果は, ショ 一トネス発現にデンプンの物性が大きく寄与し，グルテ ンの物性はほとんど無視できるということを示㖫してい る。 

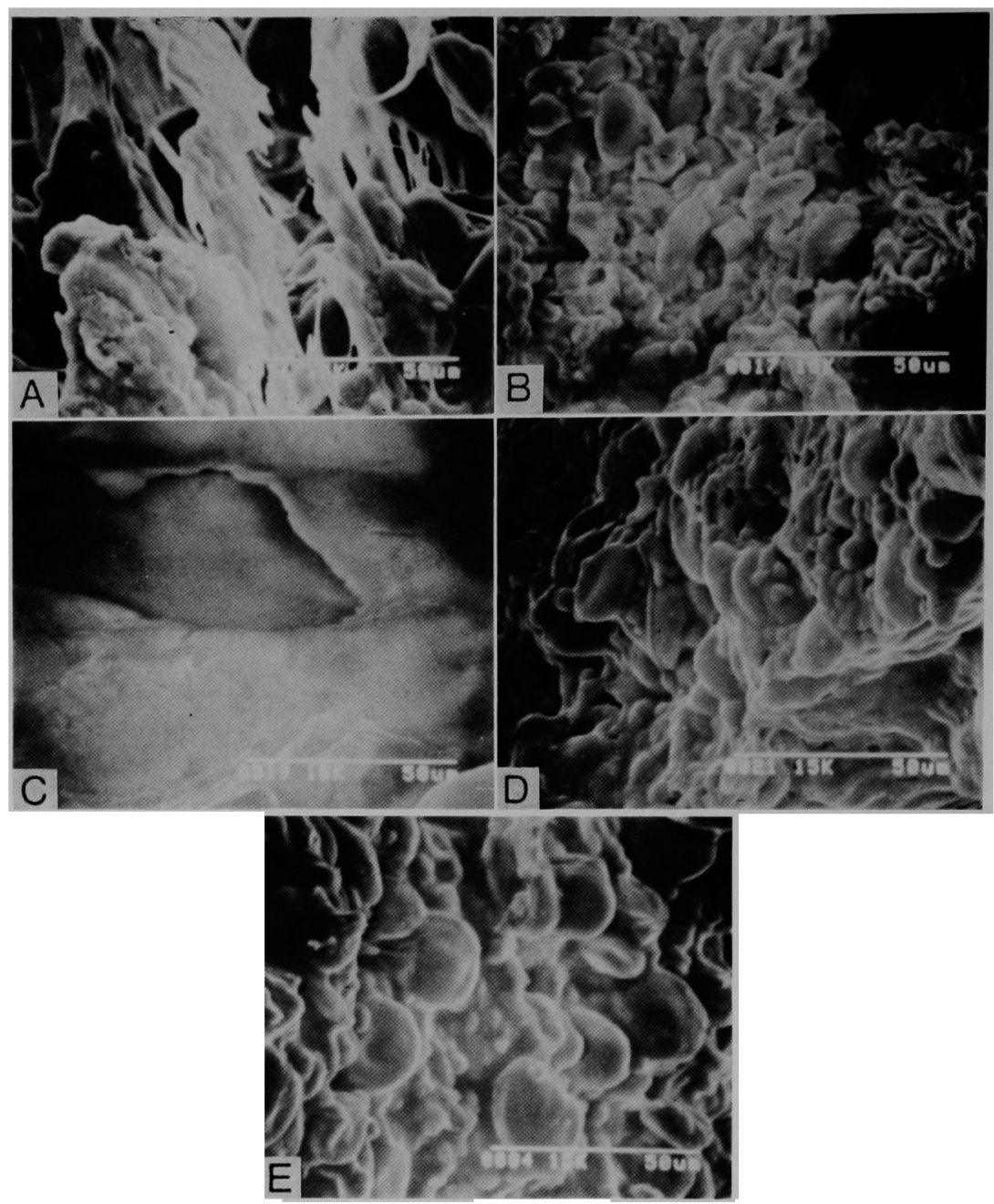

Fig. 2. Scanning electron micrographs showing microstructures of cookies (1,000 times magnification).

A, control ; B, modified starch; C, modified gluten; D, modified starchmodified gluten; and $\mathrm{E}$, reference.

小麦粉にもともと存在する脂質の作用によってクッキ 一の内部に気泡が安定に保たれるために1112)，内部構造 の連続性が乱されてショートネスが発現する場合が考え られる。本研究で得られた官能試験の結果が気泡の存在 で説明できるかどらかを確かめるために，クッキー内部 構造を走查型電子顕微鏡で観察した。ここで用いた標準 クッキー (Table 1 の reference) は前報1 でショート ネスに富むと判定された条件に準じて油脂を配合して調 製したものである。Fig.1 に示したように，標準クッキ -（E）でとくに気泡のあとが多いといらことはなかっ た。さらに, 官能試験で高いショートネススコアが得ら れたデンプン修飾クッキー（B）とデンプンとグルテン の両者を修飾したクッキー（D）でも多くの気泡が観察
されるといらことはなかった。むしろ，ショートネスス

Table 2. Shortness scores for cookies and their partial correlation coefficients calculated by the quantification method of the first type.

\begin{tabular}{lcc}
\hline \multicolumn{1}{c}{ Treatment } & $\begin{array}{c}\text { Shortness } \\
\text { score } \\
\text { (Av. } \pm \text { s.e.) }\end{array}$ & $\begin{array}{c}\text { Partial } \\
\text { correlation } \\
\text { coefficient }\end{array}$ \\
\hline None (control) & $1.04 \pm 0.02$ & - \\
Starch-modification & $4.09 \pm 0.54$ & 0.50 \\
Gluten-modification & $1.70 \pm 0.24$ & 0.03 \\
Starch-gluten-modification & $4.88 \pm 0.61$ & - \\
\hline
\end{tabular}


B.U.
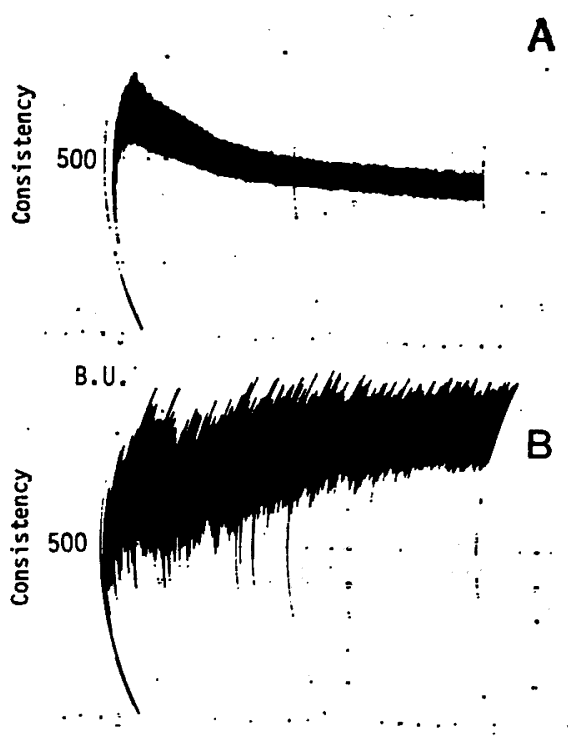

-B.U.

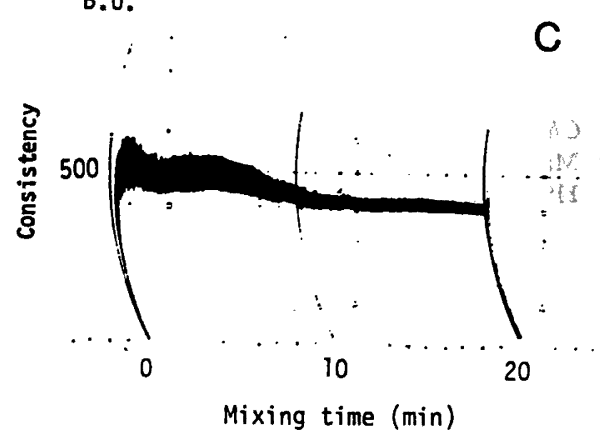

Fig. 3. Farinograms for wheat flours.

A, control; B, modified starch; and C, modified gluten.

コアの低い対照クッキー（A）で気泡は安定に保たれて いた。気泡が多ければ組織が不連続になって，砕けやす いと考えられるが, Fig.1 の結果は気泡の多少たけでは ショートネスを説明できないことを示唆している。

Fig.2 はクッキーの微細構造を示したものである。標 準クッキーでは組織の内部が不連続であって, 直径数 $\mu \mathrm{m}$ から $20 \mu \mathrm{m}$ 程度の粒状構造が認められた (E)。上 述のように，もろさを与えるためには，連続した構造は 不利であり，粒状になった個々のるのが弱くくっつき合 ったときにショートネスが発現されると考えるのが妥当 である。この標準クッキーと比較的似た構造を与えたの はテンブン修飾クッキーお゙よびデンプンとダルテンの両 者を飾したクッキーであった（Bおよび D)。これら のクッキーでは系存在するョウ素が水の存在下で加熱 によって糊化したデンブンの蹯水性空間に包接されるた めに, デンプンは膨潤しない(18)。膨潤を抑えられたデン

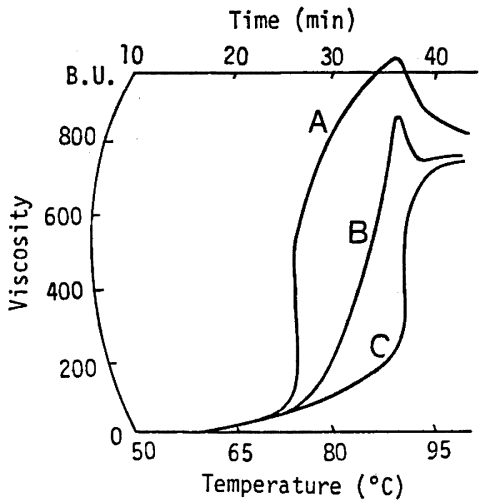

Fig.4. Amylograms for wheat starch with and without hydrogenated coconut oil.

A, starch without hydrogenated oil. B, starch: hydrogenated oil $(1: 05)$. $\mathrm{C}$, starch : hydrogenated oil $(1: 1)$.
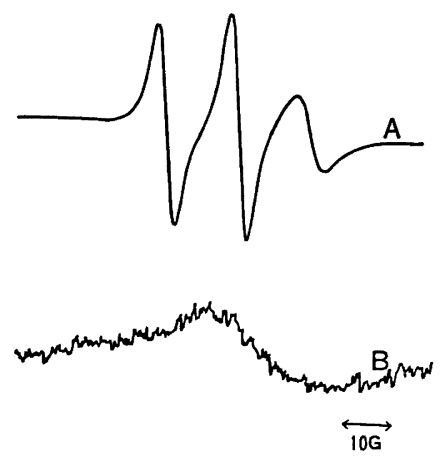

Fig.5. ESR spectra of the spin probe in corn oil (A) and in a gelatinized wheat starchcorn oil system (B).

プンはデンプン粒がいくぶん変型しただけの状態で存在 していた（Bおよび D)。これに比べてグルテン修飾ク ッキーは均一な構造を示し，デンプンがよく糊化してい て, 対照クッキー（A）で見られるようなグルテンの網 目構造も認められなかった（C)。

次いで, ファリノグラフを用いて生地物性をしらべ た。Fig.3 に示したよらに, デンプンを修飾した小麦粉 （B）からは対照（A）よりも硬くて強力な生地が形成し た。このファリノグラムは網目構造を形成しやすい強力 粉で得られるものに似ている。一方，クルテンを修飾す ると生地は柔らかくなり(C), 網目構造がない分だ組 織に連続性を与えにくい状態となった。ファリノグラム から得られた情報と走査型電子顕微鏡観察で得られた結 果を合わせて考察すると，官能的にショートネスを与え るためには主としてデンプンの膨潤を抑制することが重 要であり, 気泡の存在やクルテンの網目構造形成の阻害 はショートネス発現にあまり奇与しないと推論される。 
一般に油脂はデンブンの糊化を抑制するが，糊化温度 には影響しない14)。本研究に用いた試料においてる，

Fig.4 に示すように, デンプンの糊化膨潤による粘度の 上昇曲線が高温側にずれ，デンプンと油脂とが相互作用 している可能性が示唆された。

デンプンと油脂の相互作用には二つの様式が考えられ る。その第一はデンプン表面に油脂が吸着するといら様 式である。Seguchi15) はクッキーの影微鏡観察からこの 種の相互作用の発現を報告している。第二の様式はデン プン糊の内部に油脂がとりこまれる場合である。安定二 トロキシドラジカルの ESR スペクトルの線幅の広がり から, Nolan ら ${ }^{16)}$ は小麦, トウモロコシおよびワキシー コーンのデンプンと脂肪酸のニトロキシド誘導体がこの 様式で相互作用すると述べている。Fig.5 の ESR スペ クトルは Nolan らの結果を支持するるのである。ュー ン油中では分子回転相関時間17)が $10^{-9}$ 秒の桁の運動性 をもったスピンプローブ（Fig.5 のA）がデンプン糊と の相互作用の結果, 運動性の算定が不可能になるまで強 く束繧された状態におかれた (Fig. 5 のB)。この状態は 固体に近い状態と想像される。トリクリセリドと脂肪酸 とではデンプンとの相互作用の様相に多少のちがいがあ るかもしれないか， ESR の結果と走査型電子顕微鏡観 察の結果 (Fig.2 のE) とから, 油脂はデンプンに包接 されると考えるのが妥当である。油脂を加えることによ ってショートネスを発現させたクッキーとヨウ素をデン プンに包接させたデンプン修飾クッキーで似た構造が観 察された結果 (Fig.2) は, おそらく水の存在下で加熱さ れて膨潤したデンプンのヘリックス内部の柾水領域にト リグリセリドの脂肪酸側鎖が包接された可能性を示唆し ている。本研究に用いた水素添加ヤシ油にはほとんど遊 離脂肪酸が含まれていないので, 標準クッキーにおいて デンプンに遊離脂肪酸が包接されたためにショートネス が発現したといら可能性はない。

本研究で得られた結果を総合すると, 油脂を含むクッ キーでは小麦粉のデンプンが糊化過程でトリグリセリド の脂肪酸側鎖を包接し，極度に膨潤が妨げられるために 糊化デンプン分子による連続した構造が発達せず，砕け 易い物性が発現すると考えられる。さらに, 著者らは, ショートネス発現の主様式はグルテンの網目構造の形成 阻害ではなく, デンプンの糊化の阻害であると推論す る。

\section{要 約}

1）小麦粉，デンプン修飾小麦粉およびグルテン修飾 小麦粉から油脂無添加でクッキーを調製し, ショートネ
スを官能評価したところデンプン修飾によってショー トネスの高いクッキーが得られた。

2）デンプン修飾クッキーは油脂添加でショートネス を出させたクッキーの組織に似ていた。

3）小麦粉クッキー生地に比ベてデンブン修飾クッキ 一生地は硬く，クルテン修飾クッキー生地は柔らかかっ た。

4）油脂添加によって小麦デンプン糊の糊化が抑制さ れた。

5）脂肪酸誘導体スピンプロープ存在下で小麦デンプ ンを糊化させると,プローブの運動性が極度に低下し た。

6）以上の結果から，クッキーのショートネス発現は デンプン分子による油脂の脂肪酸側鎖の包接に起因する と推論した。

\section{文献}

1）和田淑子，倉賀野妙子，長谷川美幸 : 家政誌，34, 609 (1983)

2) 松井宣也：油化学, 19, 57 (1970)

3) Mattews, R.H. and Dawson, E.H. : Cereal Chem., 40, 291 (1963)

4) Matz, S.A.: Cookies and Cracker Technology, 119 (1968), The Avi Publishing (Westport)

5) Pomeranz, Y.: Functional Properties of Food Components, 274 (1985), Academic Press (Orlando)

6) Anderson, R.A., Pfeifer, V.F. and Lancaster, E.B.: Cereal Chem., 35, 449 (1958)

7) Stone, H., Sidel, J., Oliver, S., Woolsey, A. and Singleton, R.C.: Food Technol., 28, 24 (1974)

8）脇本和昌, 田中豊: 多変量統計解析法, 75 (1982), 現代数学社 (京都)

9) American Association of Cereal Chemists : Approved Methods of the AACC, Method 22-10 revised October 1982 and Method 54-21 approved April 1961 (1983), The Association (St. Paul)

10) Shenouda, S.Y.K. and Pigott, G.M.: J. Agric. Food Chem., 24, 11 (1976)

11) Yamazaki, W.T. and Donelson, J.R. : Cereal Chem., 53, 998 (1976)

12) Clements, R.L. : Cereal Chem., 57, 445 (1980)

13) Rundle, R.E. and French, D.: J. Am. Chem. Soc., 65, 1707 (1943)

14) Hoseney, R.C., Lineback, D.R. and Seib, P.A.: Baker's Dig., 52, 11 (1978)

15) Seguchi, M.: Cereal Chem., 61, 241 (1984)

16) Nolan, N.L., Faubion, J.M. and Hoseney, R.C.: Cereal Chem., 63, 287 (1986)

17) Waggoner, A.S., Griffith, O.H. and Christensen, C.R. : Proc. Natl. Acad. Sci., 57, 1198 (1967)

(昭和 61 年 11 月 20 日受理) 